\title{
Primary intestinal lymphangiectasia
}

INSERM

\section{Source}

INSERM. (1999). Orphanet: an online rare disease and orphan drug data base. Primary intestinal lymphangiectasia. ORPHA:90362

Primary intestinal lymphangiectasia (PIL) is a rare intestinal disease characterized by dilated intestinal lacteals which cause lymph leakage into the small bowel lumen. Clinical manifestations include edema related to hypoalbuminemia (protein-losing enteropathy), asthenia, diarrhea, lymphedema and failure to thrive in children. 